Manganese have been rcalculated by use of new thermodynamical data. The values obtained nere 2.44 and 1.05 volts, respectively.

(Received June 5, 1948)

\section{I. 緒}

一般にアルカリ金荥, フルカリ土金屬等イオン化倾何の

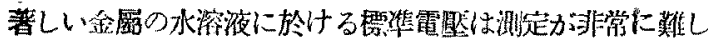
いため,從來正磪な值が得られてるない、マダネシウム、、

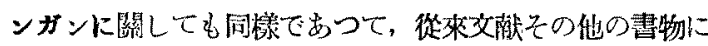

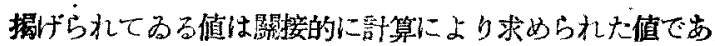
る.こ㣗等の計算に使用されてるる數值は最近の新しい熱 力學的數值と多少翼つてるるので此處に新しく部算したの である.

\section{II. $\nabla$ マネシウムの橒萑電暨}

マグネシウムの標準箧巸を求めるため次の各反應を考へ る. 期ち

$$
\begin{aligned}
& \mathrm{Mg}+\frac{1}{2} \mathrm{O}_{2}+\mathrm{H}_{2} \mathrm{O}(\mathrm{l})=\mathrm{Mg}(\mathrm{OH})_{2} \\
& \mathrm{Mg}(\mathrm{OH})_{2}=\mathrm{Mg}^{++}+2 \mathrm{OH}^{-} \\
& 2 \mathrm{OH}-=\mathrm{H}_{2} \mathrm{O}(l)+\frac{1}{2} \mathrm{O}_{2}
\end{aligned}
$$

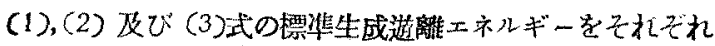

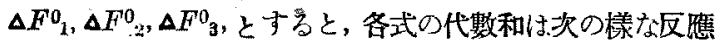
の $\Delta E^{0}$ となる。

$$
\mathrm{Mg}=\mathrm{Mg}^{++}+2 \mathrm{e}
$$

$こ の \Delta F^{0}$ は標準電堅 $E$ との間に次の關係を有する。

$$
\triangle F^{0}=-n \cdot f \cdot E^{*}
$$

こふに，nは賞量僌， $f$ はフフラデー,

(i) $\mathrm{Mg}+\frac{1}{2} \mathrm{O}_{2}+\mathrm{H}_{2} \mathrm{O}(\mathrm{l})=\mathrm{Mg}(\mathrm{OH})_{2} \Phi \Delta \boldsymbol{F}^{0}{ }_{1}$ 計算

各反慗物質のエントロピー $S$ を文献より求めると

$\mathrm{MgS}_{298}=8.3$ E.U.(1), $\quad \frac{1}{2} \mathrm{O}_{2} \mathrm{~S}_{298}=24.51$ E.U.(2)

$\mathrm{H}_{2} \mathrm{OS}_{298}=16.75 \mathrm{E} . \mathrm{U} .{ }^{(3)}, \mathrm{Mg}(\mathrm{OH})_{2} \mathrm{~S}_{298}^{-}=15.09 \mathrm{E} . \mathrm{U}$. (4) $^{(4)}$

從つ七 $\Delta S=-34.47 E . U$.

反應熱 $\Delta H$ は次の二式より求める。飠りち

$$
\text { - } \mathrm{MgO}+\mathrm{H}_{2} \mathrm{O}(\mathrm{l})=\mathrm{Mg}(\mathrm{OH})_{2} \quad \Delta H_{1}=-9735(4) \mathrm{cal} \text {. }
$$$$
\mathrm{Mg}+\frac{1}{2} \mathrm{O}_{2}=\mathrm{MgO} \quad \Delta H_{2}=-14580 \mathrm{c}^{(5)} \mathrm{cal} .
$$

徙つ大

$\mathrm{Mg}+\frac{1}{2} \mathrm{O}_{3}+\mathrm{H}_{2} \mathrm{O}(\mathrm{l})=\mathrm{Mg}(\mathrm{OH})_{2} \quad \Delta H=-155539 \mathrm{cal}$.

(1) Miething, Tabellen.

(2) Johnston u. Walker, Amer. Chem. Soc., 55, (1933), 172.

(3) Gordon, J. Chem. Pbys., 2 (1934), 65; 549.

(4). W.F. Giauque and R.G. Archibald, J. Amer. Chem. Soc., 59 (1937), 561.

(5) J.E. Morse u. E.W. Parr, Amer. Soc., 46, (1924), 2556.
以上の㪘値を Gibbs-Helmholtz の式に代入すると

$$
\Delta F^{0}{ }_{1}=\Delta H-T \Delta S=-145263 \mathrm{cal} \text {. }
$$

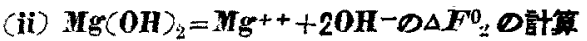

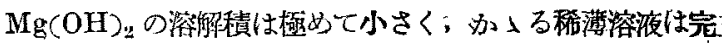
全解跳老なし，理想溶液と考へて差芳へないと思はれる。 從つて次の關係が成立つ。

$$
\Delta F^{0}{ }_{2}=-R T \ln K=-R T \ln \left[\mathrm{Mg}^{++}\right][\mathrm{OH}-]^{2}
$$

溶船棈として, $[\mathrm{Mg}++][\mathrm{OH}-]^{2}=2.3 \times 10^{-11(6)}$ を用ひると $\Delta F^{0}{ }_{2}=14510 \mathrm{cal}$.

(iii) $20 \mathrm{H}-=\mathrm{H}_{2} \mathrm{O}(\boldsymbol{V})+\frac{1}{2} \mathrm{O}_{2} \odot \Delta \mathrm{Fo}_{3}$

$\Delta F_{\mathrm{g}}=18350(7) \mathrm{cal}$.

以上の $\Delta F^{0}{ }_{1}, \Delta F^{0}{ }_{2}, \dot{\Delta} Z_{3} y_{3}$ 組合はせて

$\mathrm{Mg}=\mathrm{Mg}^{++}+2 \mathrm{e} \quad \Delta F^{0}=-112763 \mathrm{cal}$.

從つて $E=+2.44$ volts.

從來の文献としては Landolt の表より 1.55 volts刀如求 められる。こよに計算した值はこれとかなりの開まがあり 何れが正しいかは後目の检討を待たねばならぬ.

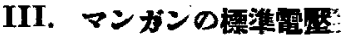

マンガンの橙焦電篹を求めるため, 次の各反應を利用す る.

$$
\begin{array}{ll}
\mathrm{Mn}+\mathrm{S}(r)=\mathrm{MnS} & \Delta F_{{ }_{1}}^{0}=-45135 \mathrm{cal},(8) \\
\mathrm{S}(r)=\mathrm{S}-- & \Delta F^{0}{ }_{2}=23475 \mathrm{cal},(9) \\
\mathrm{Mn}+++\mathrm{S}-{ }^{(9)}=\mathrm{MnS} & \Delta F^{0_{3},}
\end{array}
$$

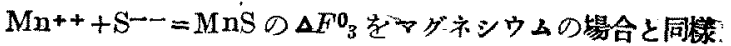
溶船積より求女ると, $\left[\mathrm{Mn}^{++}\right]\left[\mathrm{S}^{-}-\right]=1.4 \times 10^{-15}$ (10)

$\Delta F_{\beta}^{0}=-20256$ cal.

以上の $\Delta F^{0}{ }_{1}, \Delta F^{0}{ }_{2}, \Delta F^{0}{ }_{3}$ を組合はせて

$$
\mathrm{Mn}(s)=\mathrm{Mn}+++2 \mathrm{e}
$$

$\Delta F^{0}=-48354 \mathrm{cal}$.

$E=+1.05$ volts.

從來の值は Landolt の表より 1.00 voltg にて略々一致し てるる.

(6) Britton, J. Chem. Soc., 27 (1925), 2118.

(7) Lewis and Randal], Thermodynamics, (1923).

（8）传野, 服部報公會研究報告, 10 (1943), 12.

(9) 木村,理研策報, 14 (1935)，94.

(10) Landolt, Tabellen, (1923), 1184.

\title{
石灰の吸濕速度について（第1 報)
}

传野幸吉* 坂尾弘*

Kökichi Sano and Hiroshi Sakao :

On the Hydration Velocity of Lime (Part I). The effects of the ignition temperature and the hydration temperature upon the hydration 
velocity of the chemical pure lime were investigated by the dynamic method. From the results obtained, it was reccognized expectedly that the hydration velocity increases as the ignition temperature decreasee. Hoxever, the hydration velocity decreases as the hydration temperature increases in spite of the opposite direction of relation anticipated from the general theory of the reaction velocity.

(Received June 5,1948)

\section{I. 锗 言}

化學成分を同しくする石灰でるその反隹性に美暴がある ことはよく知られてるる。この原因を根本的に究明する には，吻淪石灰石の成因について研究が必要であるが，先 つ石灰の吸滋速度について葢驗を行つた，石灰つ吸濕速度

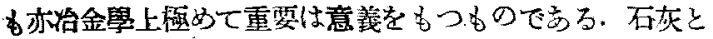
水蒸氣との間の平面についてはLe Chatelier('), Johnston

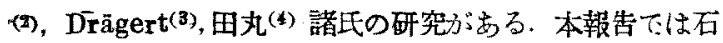

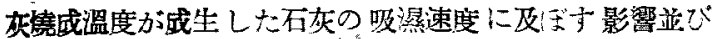

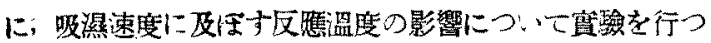
た

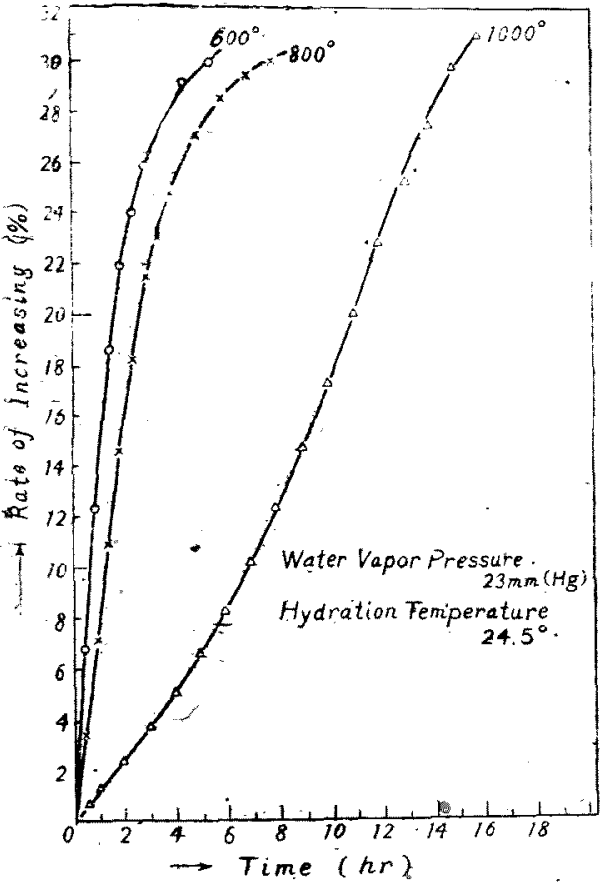

Fig. 1 The Effect of Ignition Temperature on the Hydration Velocity of the Chemical Pure Lime.

\section{II. 及び測定结果}

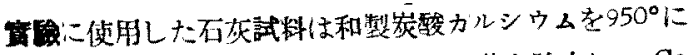

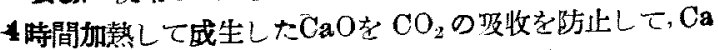
$(\mathrm{OH})_{2}$ となし，この预備試科 $\mathrm{Ca}(\mathrm{OH})_{2}$ を需驗の度每に所 定の温度で铣成して作製した。

(1) Ie Chatelier. Compt. Rend., 102 (1886), 1243.

(2) Johnston, Z. Phys. Chem., 62 (1908), 330.1

(3) Drägert, Landolt-Bōrnstein 'rabellen, 5, Aufl., II, (1438).

(4) 田丸, 日本化舉會誌, 53 (1932), 1169.

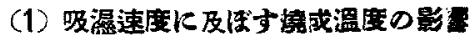

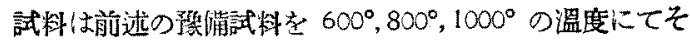

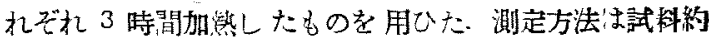

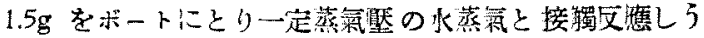

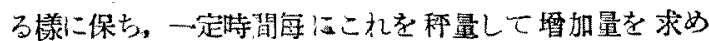

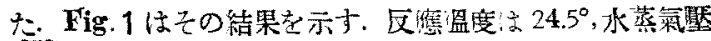
は23mm(Hg)であつたＦig1より明らかなように隽成 温度の高い程吸濕速度は小となる。溫度が $600^{\circ}, 800^{\circ}$ のも

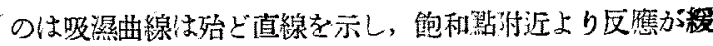
慢となり，水酸化カルシウムのみの吸著曲線を示してる る. $1000^{\circ}$ に燒成したものは時間と共に反應速度が大とな ら、上方に凹なる曲線を與一る。これは反烣の淮行と共に 反應面が急霄することによるものと考へられる。

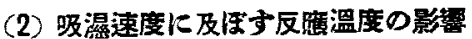

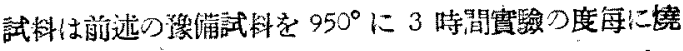
成して作製した：滥定方法は試科的 $1.5 \mathrm{~g}$ をボートに入れ， これを所定の反應溫度に保つな磁製管中に置く、又精整し

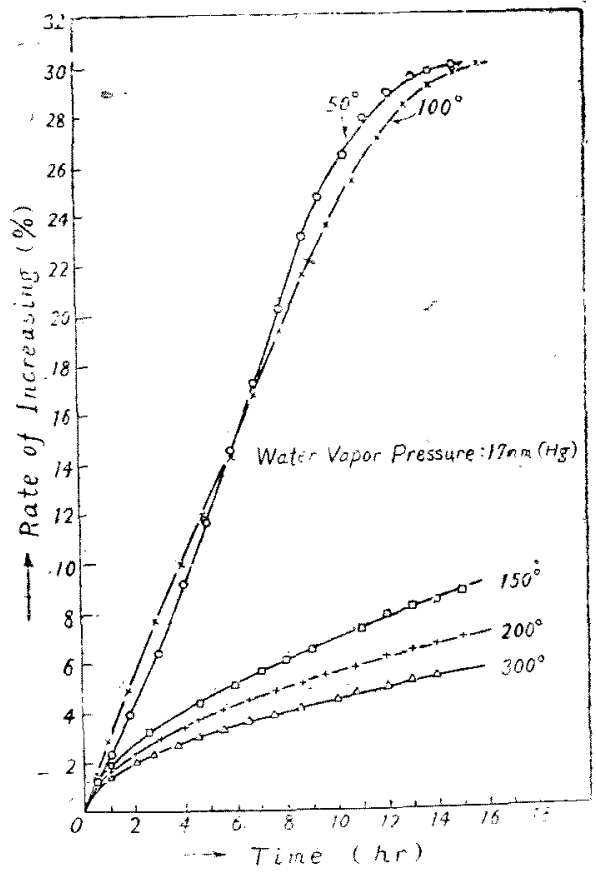

Fig. 2 The Effect of Hydration Temperature on the Hydration Velocity of the Chemical Pure Lime.

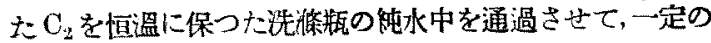
水蒸氣を含んた $\mathrm{O}_{2}$ 氮流を試看つ上に一定速度 $(50 \mathrm{cc} / \mathrm{min})$ で通して反應せしめ，所定の時間每に取出して重量つ堵前

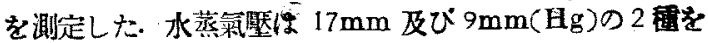


とり，反㤵溫度は $50^{\circ}, 100^{\circ}, 150^{\circ}, 200^{\circ}, 300^{\circ}$ の 5 種走とつ

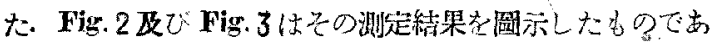

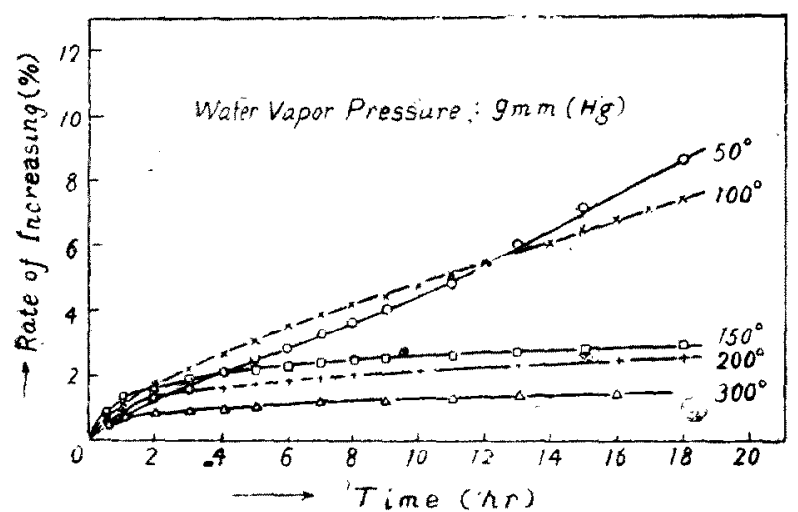

Fig. 3 The Effect of Hydration Temperature on the Hydration Velocity of the Chemical Pure Lime.

る. 圆より明らが漾に $50^{\circ}, 100^{\circ}$ の group は $150^{\circ}$ 以上 のgroupに比較して区應速度が早く，碂ど時間と直線關保 をなしてるる。

150以上では反麾溫度か高くなるに從つて反應速度は小

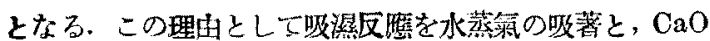
$+\mathrm{H}_{2} \mathrm{O} \rightarrow \mathrm{Ca}(\mathrm{OH})_{2}$ の反應との二つにわけて考へると, 四 澱應の初期に出いては，水蒸氣は $\mathrm{CaO}$ に直接吸著され
て值ちに区䈍して $\mathrm{Ca}(\mathrm{OH})_{2}$ となる( ${ }^{(5)}$ ，表面及びその附近

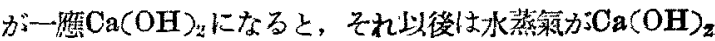
に吸著され，それが㨨散して內部の $\mathrm{CaO}$ と反應

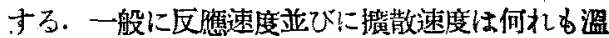
度の上年する程大となるものであるから結局吸愍

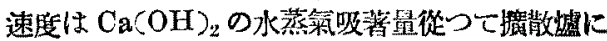
括计る濃度勾配によつて 支配さ机ると考人られ る. 郎ち $50^{\circ}, 100^{\circ}$ の group は $\mathrm{Ca}(\mathrm{OH})$, 層水蒸 氮吸著题が $150^{\circ}$ 以上の group に比較して大です ることによるものと考へら机る。こ机ついては 第2報に報告する。

\section{III. 結 論}

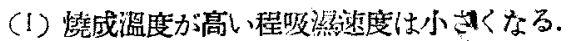
$1000^{\circ}$ の場合は自臅的反焦速度を示才。

（2）反應泪度の影響は $50^{\circ}, 100^{\circ}$ の group は加。 なり反應速度が年く、時间と增加率とは殆ど直線 關保をなす， $150^{\circ}$ 以上の groupはと扎比して。 反㗹速度は小さく，かつ同じgroupにつ、ては反㷳溫度の. 上断する程反雔速度は小さくなる。

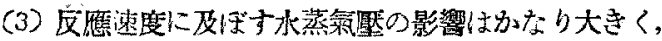
叚の高い程反應述度は大となる。

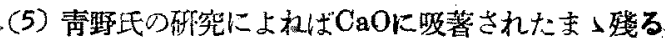

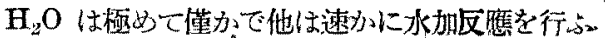
- [毒野, Bull. Chem. Soc. Japan., 6(1\%31)].

\section{石灰の吸濕速度について（第2報）}

佐野莩、吉* 坂尾 . 弘

Kókichi Sano and Hiroshi Sakao : On the Hydration Velocity of Lime (Part

II). On the adsorption equilibrium of water vapon by the chemical pure $\mathrm{Ca}(\mathrm{OH})$, some isothermal and isobaric lines were determined by means of the statical method, and the following relations were obtained. The adsorbed amounts of $\mathrm{H}_{2} \mathrm{O}$ by $\mathrm{Ca}(\mathrm{OH})_{2}$ at $50^{\circ} \mathrm{C}$ and $100^{\circ} \mathrm{C}$ have been found to be more than the values at $150^{\circ} \mathrm{C}$ and $200^{\circ} \mathrm{C}$. From this observed relation between the adsorbed amounts and the adsorption temperature, it is concluded that the hydration velocity of lime must be increased as the hydration temperature decreases.

(Received June 5, 1948),

\section{I. 緒 震}

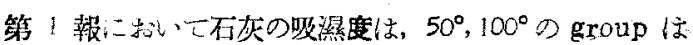
150凶1のれれよりるかなり早い，而してその理明として $\mathrm{Ca}(\mathrm{OH})_{2}$ の水蒸気吸著翼の大小によるのではないからとい

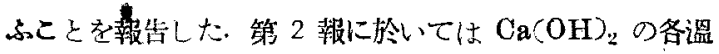

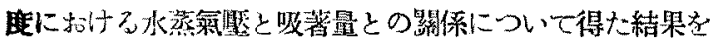
報告子る。

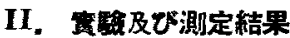

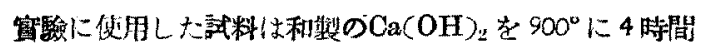

加熱し次にこ札をCO竞除去した純水を入れしたデシケータ

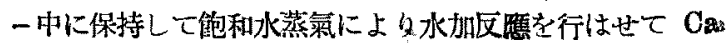
$(\mathrm{OH})_{2}$ としたものを用ひな，湘定は Fig. 1 に示技如き 装置を用ひて行うた。

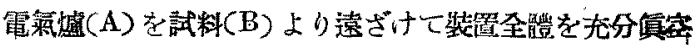

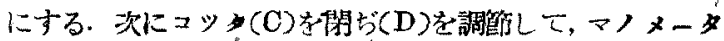
一(E)中に水銀を入机る。次にコック(F)，(G)を閉ぢ，電 氣曥を動加して訊料を听定の溫度に保ち，壓力が一定にな つたときその厘力、 ( P mm.Hg.)を望む。，次にコック(I)を

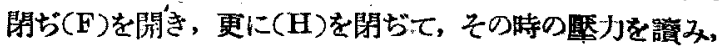
预め䁚しである(J)及び(K)內の容䅡より，標準肤况に相 